\title{
Case Report: Addition of Naltrexone and Bupropion to Lorcaserin to Manage Olanzapine-induced Weight Gain
}

\author{
Kevin Bera', Eric Tran² and Charles T. Nguyen ${ }^{3 *}$ \\ ${ }^{1}$ University of Southern California, USA \\ ${ }^{2}$ Long Beach Veterans Affairs, USA \\ ${ }^{3}$ Department of Psychiatry, UC Irvine Medical Center, USA
}

*Corresponding author: Charles T. Nguyen, MD, Professor of Psychiatry at UC Irvine Medical Center, Long Beach Veterans Affairs, California, USA, Tel: 714-351-7820, E-mail: Charles.song.nguyen@gmail.com

\section{Introduction}

Antipsychotic medications, both typical and atypical, share the potential side effect of weight gain with atypical agents carrying a greater risk. Atypical antipsychotics, such as clozapine and olanzapine, which antagonize the 5-hydroxytryptamine (serotonin) subtype $5-\mathrm{HT}_{2 \mathrm{C}}$ receptor, have been associated with a higher likelihood to induce weight gain [1].

The use of a selective $5-\mathrm{HT}_{2 \mathrm{C}}$ agonist such as lorcaserin has been used to counter the $5-\mathrm{HT}_{2 \mathrm{C}}$ antagonism of olanzapine [2]. Locaserin promotes satiety and decreased food intake by activating the $5-\mathrm{HT}_{2 \mathrm{C}}$ receptors on anorexigenic pro-opiomelanocortin (POMC) neurons in the hypothalamus [3]. The receptor affinity, $\mathrm{Ki}$, of lorcaserin and olanzapine for the $5-\mathrm{HT}_{2 \mathrm{C}}$ receptor are 13 and 14, respectively [4]. Given the similar Ki between lorcaserin and olanzapine, lorcaserin theoretically may not be able to dislodge the antagonism of $5-\mathrm{HT}_{2 \mathrm{C}}$ by olanazapine. Therefore, using a different mechanism of action may counter the effects of weight gain induced by olanzapine.

Bupropion, an amino-ketone, is thought to increase the firing rates of the POMC neurons in the medial portion of the arcuate nucleus. This increases satiety and reduces food intake. POMC is cleaved into active peptides, $\alpha$-melanocyte stimulating hormone ( $\alpha-\mathrm{MSH})$ and $\beta$-endorphin. $\alpha$-MSH causes increased energy expenditure and decreased food intake. $\beta$-endorphin autoinhibits POMC neurons via mu-opioid receptors; therefore, promoting food consumption [5]. Naltrexone, a pure opioid antagonist with a high affinity for the muopioid receptor, blocks the autoinhibitory feedback of $\beta$-endorphin, thus leading to a longer-lasting activation of the POMC neurons. The combination of bupropion and naltrexone is thought to produce a substantially greater effect on the firing rate of the POMC neurons than either medication by itself, leading to decreased cravings and reduced food intake [6].

\section{Clinical Case}

This is a case report of a patient with olanzapine-induced weight gain. A 36 year-old Caucasian male with obsessive compulsive disorder and schizophrenia had been stable on olanzapine $30 \mathrm{mg}$ qhs, risperidone $2 \mathrm{mg}$ qam, $4 \mathrm{mg}$ qhs, setraline $200 \mathrm{mg}$ qam, and clonazapam $0.5 \mathrm{mg}$ bid since 2012 . He was started on olanzapine back in 2007 and gained almost 70 pounds. Several attempts to discontinue olanzapine were unsuccessful due to re-emergence of symptoms.

Lorcaserin $10 \mathrm{mg}$ bid was begun in February 2015, his weight was 261 and his fasting insulin was $4.9, \mathrm{HbA1C}=5.5$. The patient was unable to control his eating habit due to his worsening depression. He was started on bupropion $150 \mathrm{mg}$ qam in July 2015. Bupropion was increased to $150 \mathrm{mg}$ bid to control the depressive episodes.

In October 2015, his weight was 271 pounds with fasting insulin of 20, triglyercide of 328 and $\mathrm{HbA1C}$ of 5.4 . He had tremendous food cravings, leading to eating multiple, high-carbohydrate meals at night. He said that the lorcaserin was helping with the sensation of fullness, but he was unable to fight the food cravings. Therefore, naltrexone $25 \mathrm{mg}$ qam was initiated in an attempt to help reduce his food cravings. A month later, the patient reported decreased food cravings and weighed in at 259 pounds. By December 2015 his weight was reduced to $251 \mathrm{lbs}, \mathrm{HbA1C}$ was 5.1. The patient remains on treatment.

\section{Discussion}

Certain atypical antipsychotics, such as olanzapine, have been known to induce weight gain via $5-\mathrm{HT}_{2 \mathrm{C}}$ receptor antagonism. In this case study, the patient had no response to lorcaserin for weight loss. Even though the patient felt full, he was unable to control his cravings and poor eating habits, especially at night. His eating patterns may have worsened due to his worsening depressive symptoms. Once the depression was under controlled with wellbutrin, the patient still had a difficulty losing weight until naltrexone $25 \mathrm{mg}$ qam was added to bupropion 150mg bid and lorcaserin $10 \mathrm{mg}$ bid. While the satiety may have been addressed with lorcaserin, it was not until the addition of naltrexone that helped him control his cravings and resulted in reduced food intake. Bupropion and naltrexone have both been shown to achieve weight loss through their interaction with POMC neurons and in combination produce a further beneficial synergistic effect.

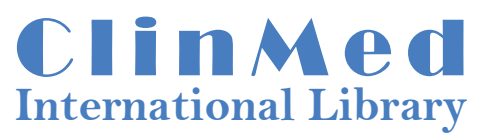

Citation: Bera K, Tran E, Nguyen CT (2016) Case Report: Addition of Naltrexone and Bupropion to Lorcaserin to Manage Olanzapine-induced Weight Gain. Int Arch Clin Pharmacol 2:004

Received: May 30, 2015: Accepted: January 22, 2016: Published: January 25, 2016 Copyright: ( 2016 Bera K, et al. This is an open-access article distributed under the terms of the Creative Commons Attribution License, which permits unrestricted use, distribution, and reproduction in any medium, provided the original author and source are credited. 
Table 1: Weight and Hemoglobin A1 Changes.

\begin{tabular}{|c|c|c|c|c|}
\hline & Feb. 2015 & July 2015 & Oct. 2015 & Dec. 2015 \\
\hline Weight & 261 & 273 & 271 & 251 \\
\hline $\mathrm{HbA} 1 \mathrm{C}$ & 5.5 & 5.7 & 5.4 & 5.1 \\
\hline Medications (mg) & Olanzapine 30 & $\begin{array}{l}\text { Olanzapine } 30 \\
\text { Locarserin } 20\end{array}$ & $\begin{array}{l}\text { Olanzapine } 30 \\
\text { Locarserin } 20 \\
\text { Wellbutrin } 300\end{array}$ & $\begin{array}{l}\text { Olanzapine } 30 \\
\text { Locarserin } 20 \\
\text { Wellbutrin } 300 \\
\text { Naltrexone } 25\end{array}$ \\
\hline
\end{tabular}

\section{Conclusion}

This case report demonstrates the potential use of naltrexone and bupropion combination as an adjunctive treatment along with lorcaserin in the management of olanzapine-induced weight gain in patients with schizophrenia who exhibit depressive symptoms. This report will continue to add to the growing literature of using novel pharmacologic combinations to help patients with schizophrenia achieve weight loss while maintaining symptom stability (Table 1).

\section{References}

1. Horacek J, Bubenikova-Valesova V, Kopecek M, Palenicek T, Dockery C et al. (2006) Mechanism of action of atypical antipsychotic drugs and the neurobiology of schizophrenia. CNS Drugs 20: 389-409.
2. Nguyen C, Suzuki A, Bera K (2015) Use of lorcaserin, a 5-HT2c agonist in the management of olanzapine-induced weight gain. J Metabolic Synd 4: 190.

3. Shukla AP, Kumar RB, Aronne LJ (2015) Lorcaserin Hcl for the treatment of obesity. Expert Opin Pharmacother 16: 2531-2538.

4. Thomsen WJ, Grottick AJ, Menzaghi F, Reyes-Saldana H, Espitia S, et al (2008) Lorcaserin, a novel selective human 5-hydroxytryptamine2C agonist: in vitro and in vivo pharmacological characterization. J Pharmacol Exp Ther 325: $577-587$.

5. Ali KF, Shukla AP, Aronne LJ (2016) Bupropion-SR plus naltrexone-SR for the treatment of mild-to-moderate obesity. Expert Rev Clin Pharmacol 9: 27-34.

6. Greenway FL, Fujioka K, Plodkowski RA, Mudaliar S, Guttadauria M, et al. (2010) Effect of naltrexone plus bupropion on weight loss in overweight and obese adults (COR-I): a multicentre, randomised, double-blind, placebocontrolled, phase 3 trial. Lancet 376: 595-605. 